\title{
Configurações
}

Revista de sociologia

\section{Hermínio Martins, Experimentum Humanum - Civilização tecnológica e condição humana}

\section{Rita Correia}

\section{(2) OpenEdition}

1 Journals

\section{Edição electrónica}

URL: http://journals.openedition.org/configuracoes/774

DOI: $10.4000 /$ configuracoes. 774

ISSN: 2182-7419

\section{Editora}

Centro de Investigação em Ciências Sociais

\section{Edição impressa}

Data de publição: 5 fevereiro 2011

Paginação: 175-178

ISSN: 1646-5075

\section{Refêrencia eletrónica}

Rita Correia, « Hermínio Martins, Experimentum Humanum - Civilização tecnológica e condição humana », Configurações [Online], 8| 2011, posto online no dia 21 fevereiro 2013, consultado o 22 setembro 2020. URL : http://journals.openedition.org/configuracoes/774 ; DOI : https://doi.org/10.4000/ configuracoes.774

Este documento foi criado de forma automática no dia 22 setembro 2020. 


\title{
Hermínio Martins, Experimentum Humanum - Civilização tecnológica e condição humana
}

\author{
Rita Correia
}

\section{REFERÊNCIA}

Hermínio Martins, Experimentum Humanum - Civilização tecnológica e condição humana, 2011, Relógio D’Água.

1 Editado em Maio de 2011 pela Relógio D'Água, o livro Experimentum Humanum Civilização tecnológica e condição humana agrega, pela primeira vez, diversos artigos publicados por Hermínio Martins no âmbito do que designa por sociologia filosófica da tecnologia e da civilização tecnológica, dando corpo e demonstrando a coerência do trabalho que o autor tem vindo a desenvolver no decurso das últimas décadas. Como é claramente assumido no prefácio, este livro não procura apresentar qualquer "sistema fechado" ou apontar alguma "utopia ou distopia em particular", mas antes sugerir pistas de investigação e reflexão sobre a civilização tecnológica livres de "preconceitos metodológicos, dogmas de escola e confinamentos disciplinares".

2 Hermínio Martins ${ }^{1}$ nasceu em 1934, na cidade de Lourenço Marques (actual Maputo), em Moçambique. Tendo feito o percurso escolar na sua cidade natal, e arredadas as hipóteses da vinda para a metrópole devido ao seu envolvimento em movimentos de discussão cultural e de resistência à ditadura ou da ida para a África do Sul pela sua recusa em trocar uma estrutura de dominação racial por outra semelhante, em 1952 opta por prosseguir os seus estudos na London School of Economics, em Londres. Foi em Inglaterra que teve professores como Karl Popper, Michael Oakeshott e Ernest Gellner e se licenciou, em Economia com especialização em Sociologia, com distinção. Foi professor nas Universidades de Leeds (1959-64), Essex (1964-71), Harvard (1966-67), Pennsylvania (1967-68) e Oxford (1971-2001), onde teve oportunidade de partilhar 
discussões com académicos como John Rex, Bryan Wilson, Peter Nettl, Jerry Ravetz, Talcott Parsons, John Rawls, David Riesman, Imre Lakatos, entre muitos outros. Passou à condição de Emeritus Fellow na Universidade de Oxford em 2001 e foi então convidado a ingressar no Instituto de Ciências Sociais da Universidade de Lisboa, onde é hoje Investigador Honorário.

Experimentum Humanum - Civilização tecnológica e condição humana é composto por nove capítulos, divididos em três partes, num total de 448 páginas. A primeira parte tem como título "Pensar a técnica: questões preliminares" e inclui os quatro primeiros capítulos: "Hegel, Texas: temas de filosofia e sociologia da técnica", pp. 15-36; "Tecnologia, modernidade e política", pp. 37-69; "O Deus dos artefactos: o princípio de Vico e a tecnologia", pp. 70-143; e "Tecnociência e arte", pp. 144-170. As versões originais dos textos que compõem esta primeira parte tinham sido publicadas em obras dispersas, maioritariamente escritas em inglês, e foram alvo de uma considerável ampliação para o presente livro (cerca de setenta páginas no total dos quatro capítulos). O capítulo I aborda três importantes temas de filosofia e sociologia da técnica: a tecnologia como extensão do ser humano; o gnosticismo tecnológico; e as aplicações tecnológicas. Já no capítulo II são destacadas: a civilização técnica como póshistória; versões finitas e infinitas do projecto prometeico; e a imagem fáustica da técnica. O capítulo III é dedicado à análise do modo como, ao longo dos séculos, o desenvolvimento científico tem estado assente em fé, promessas e expectativas de vária ordem. As relações entre tecnociência e arte constituem o mote para o capítulo IV.

4 A segunda parte, "Do trágico tecnológico", inclui três capítulos: "Risco, incerteza e escatologia", pp. 173-231; "Experimentos com humanos, guerra biológica e biomedicina tanatocrática", pp. 232-277; e "Para uma sociologia das calamidades", pp. 278-329. Também estes capítulos resultam de uma significativa ampliação (cerca de trinta páginas) e revisão dos textos originais. Abrindo a segunda parte, o capítulo $\mathrm{V}$ versa sobre as questões da análise do risco tecnológico, da insuficiência do conceito de risco e necessidade do conceito de incerteza e do princípio de precaução. No capítulo VI o autor apresenta o que ele próprio denomina de "história trágico-científica", chamando a atenção para a existência de aspectos menos épicos e nobres, tais como a experimentação em seres humanos, a guerra biológica ou a guerra científica. $O$ capítulo VII é reservado à emergência das calamidades como campo de estudo, nomeadamente mediante o aprofundamento dos princípios de plenitude (clássico, de plenificação tecnológica e de plenitude da vida), de uniformidade e de substitutabilidade infinita.

Por último, a terceira parte é dedicada à "Passagem para o pós-humano" e é composta por dois capítulos, igualmente revistos para a presente edição: "Aceleração, progresso e experimentum humanum", pp. 333-389; e "Biologia e política: eugenismos de ontem e de hoje”, pp. 390-442. Nesta que é a última parte da obra, o capítulo VIII desenvolve o tema da aceleração através da análise das variedades do aceleracionismo, das relações entre aceleração e população e da tendência de aceleração para singularidade. 0 capítulo IX trata do conceito de eugenismo, refletindo sobre as interpenetrações entre biologia e política.

6 Nesta obra, partindo de uma vasta reflexão sobre os pressupostos, contextos e aspirações subjacentes ao desenvolvimento científico e tecnológico moderno, Hermínio Martins abre a porta e convida-nos a enveredar com ele pelas sendas do pensamento sobre a tecnologia e a ciência. História, filosofia, sociologia, são alguns dos campos disciplinares que podem ser identificados no percurso trilhado e que apresenta como 
principal fito o livre entendimento, o mais possível isento e emancipado de quaisquer escolhos que o possam toldar.

7 Chegamos depois a uma segunda etapa da nossa rota em que somos desafiados a olhar a ciência e a tecnologia através das suas facetas menos divulgadas e conhecidas. Conceitos como incerteza, eugenia, guerra científica ou calamidade, e práticas como a experimentação biomédica, a biomedicina tanatocrática industrializada ou a adopção do princípio de plenitude tecnológica, surgem neste encadeamento de modo desassombradamente claro e somos como que catapultados para um diferente patamar. Neste terceiro plano, os valores morais, éticos e de bem comum despontam como indissociáveis da noção de Humanidade, não apenas no seu sentido biológico mas igualmente naquele que o aproxima de distintivos virtuosos como a solidariedade, a empatia ou a benevolência. $\mathrm{O}$ autor mostra que aceleração, aperfeiçoamento genético $\mathrm{e}$ crescimento económico não são os únicos caminhos de persecução da felicidade e que existem trilhos alternativos.

9 Não pretendendo aqui antecipar quaisquer resumos ou conclusões que, desde logo, poderiam resultar de certo modo contrários aos objectivos assumidos no prefácio, recomendamos vivamente a leitura deste livro, de largo horizonte intelectual, que nos exorta à investigação e ponderação humanista sobre a actual civilização tecnológica. É, sem dúvida, uma importante obra do autor português no âmbito da sociologia e filosofia da ciência e da tecnologia.

\section{NOTAS}

1. Para uma ampla explanação sobre o percurso e pensamento de Hermínio Martins, ver a introdução ao livro Razão, Tempo e Tecnologia: Estudos em homenagem a Hermínio Martins (Imprensa de Ciências Sociais, 2006) da autoria de José Luís Garcia.

\section{AUTORES}

\section{RITA CORREIA}

Instituto de Ciências Sociais da Universidade de Lisboa rita.correia@ics.ul.pt 